\title{
Path analysis of agronomic traits in soybean cultivars with determinate and indeterminate growing habits
}

\section{Vinícius Jardel Szareski ${ }^{1}$, Ivan Ricardo Carvalho ${ }^{1}$, Gustavo Henrique Demari ${ }^{1}$, Kassiana KehI ${ }^{2}$, Guilherme Pelissari ${ }^{3}$, Alan Junior de Pelegrin ${ }^{1}$, Maurício Horbach Barbosa ${ }^{3}$, Tiago Corazza da Rosa ${ }^{1}$, Nathan Lobler dos Santos ${ }^{1}$, Tamires da Silva Martins ${ }^{1}$, Maicon Nardino ${ }^{1}$, Tiago Pedó ${ }^{1}$, Velci Queiróz de Souza ${ }^{4}$, Tiago Zanatta Aumonde ${ }^{1}$}

\author{
${ }^{1}$ Universidade Federal de Pelotas, Capão do Leão, RS, Brazil \\ ${ }^{2}$ Fundação Pró-Sementes, Passo Fundo, RS, Brazil \\ ${ }^{3}$ Universidade Federal de Santa Maria, Frederico Westphalen, RS, Brazil \\ ${ }^{4}$ Universidade Federal do Pampa, Dom Pedrito, RS, Brazil
}

\section{*Corresponding author: viniciusszareski@gmail.com}

\section{Abstract}

The aim of this study was to determine associations of cause and effect agronomic traits with grain yield in contrasting growth habits of soybean genotypes, as well as to verify the magnitude of similar behaviors in different growing environments. The trials were conducted for one crop season using randomized blocks design arranged in factorial scheme, including two growing environments (Independência - RS and Tenente Portela - RS) x four genotypes (FPS Solimões RR e FPS Júpiter RR; BRS Tordilha RR and Fepagro 36 RR, 2 indeterminate and 2 determinate growing habits, respectively) in three replications. Ten important soybean yield components were evaluated. The data were subjected to individual analysis of variance for each environment and growing habits. For each environment within habits, the phenotypic path analysis was performed among the traits. The components number of pods on the main stem, number of ramifications, number of pods in the ramifications, and number of one and two-grain pods presented contrasting results in growing environments. The number of three-grain pods is among the components mostly related to grain yield for both determinate and indeterminate growing habit genotypes, regardless of the environment. The adoption of genotypes with higher weight of thousand grains may provide satisfactory results for grain yield, regardless of the growth habit and environment of cultivation.

Keywords: Glycine max L., growth environment, yield potential.

Abbreviations: IGH_cultivars of indeterminate growth habit, DGH_cultivars of determined growth habit, FPI_first pod insertion height, PH_plant height, PNMS_pods number on the main stem, RN_ramification number, PNR_pods number on the ramification, NONEGP_number of one grain pods, NTWOGP_number of two grains pods, NTHREEGP_number of three grains pods, TGW_thousand grains weight, GY_grain yield.

\section{Introduction}

The Soybean (Glycine max L.) is characterized as the major oleaginous grown in Brazil, placing the country among the world's largest producers. It is mainly due to the extensive areas of cultivation, adaptability, and existence of many developed genotypes, the factors that contribute to the production increase (Sediyama, 2009). The knowledge of traits that most influence soybean yield is important, especially understanding expression of genotypes under different environments (Almeida et al., 2010; Szareski et al., 2016). Grain yield depends on the combination of several traits (Nogueira et al., 2012).

Genotypes with contrasting growth habit have different phenotypic characteristics, where environmental conditions may act on these traits, minimizing or maximizing the genotype responses. According to Falconer (1987) significant relationships involved on correlation coefficients are justified by linkage and pleiotropism. Almeida et al. (2010) reported that environment may cause interconnection of traits, which may help or hinder the correlations. Thus, effects of correlations for environments should be analyzed.

Soybean plants with determinate growing habit almost complete their vegetative cycle before the beginning of flowering. The plants with determinate habit can grow approximately $10 \%$ to $13 \%$ of their height after flowering. When the plants grow in height was stopped, thickening of the main stem occurs. In these plants, the main stem has terminal bud with racemic inflorescence. Generally, there is a branching of variable length at each node (Borém, 2000; Sediyama et al, 2009). However, indeterminate growth habit genotypes simultaneously develop their vegetative (growth) and reproductive (flowering) stages. In other words, they keep increasing height for a relatively long period after 
starting flowering. Generally, they duplicate their height after the first flower appearance. Indeterminate plants do not present terminal inflorescence, only axillary inflorescences. They also present a tapered stem with little or absent secondary lateral growth (ramifications) near the main stem tip (Sediyama et al, 2009; Mundstock and Thomas, 2005; Baigorri and Gassen, 2009).

The knowledge of direct and indirect correlations about determined yield component, especially grain yield, enables the breeder to use this additional information to precisely discard or promote the genotypes of interest (Pandini et al., 2002). The correlation between traits allows the indirect selection of a quantitative trait of difficult gain with selection, through the selection of another trait directly correlated to it, with greater genetic gain or easy visual selection (Pipolo et al., 2005).

True relations may be achieved through path analysis (Wriht, 1921), which reveals the true cause and effect between traits. Path analysis can reveal direct and indirect linear correlation among the characters over the dependent variable, allowing accurate identification of the relations. The correlations dismemberment in direct and indirect effects aids on interpreting the relationships between the main yield components and their contribution in different environments.

Therefore, the aim of this study was to determine associations of the cause and effect of agronomic traits with grain yield in soybean genotypes with contrasting growing habit, as well as to verify the presence and magnitude of similar behaviors in different growing environments.

\section{Results and Discussion}

The variance analysis revealed significant interaction for determinate growth habit (DGH) between growing environments $\mathrm{x}$ genotypes for the traits first pod insertion height (FPI), thousand grains weight, thousand grains weight (TGW), pods number on the ramification (PNR), number of three-grain pods (NTHREEGP), and grain yield (GI). The indeterminate growth habit (IGH) revealed interaction between growing environments $\mathrm{x}$ genotypes for the traits first pod insertion height (FPI), plant height $(\mathrm{PH})$, and thousand grains weight (TGW). It demonstrates that the effects or variations evidenced in the genotypes traits in different growing environments are contrasting according to the growing habit of plants.

First pod insertion height (FPI) presents low direct magnitudes for DGH on grain yield in both environments (0.12 and 0.15 ), revealing no relation of cause and effect. However, the indirect effects of other characters such as PH and PNMS for Independência - RS are high (0.25 and -0.43). The linear correlation in Tenente Portela-RS presents magnitude higher than the direct effects. Such a relationship is observed due to the indirect effects by NTHREEGP (0.34). Cruz et al., (2004) revealed that low correlation between characters does not indicate absence of relationship between variables, but lack of linearity between the parameters. Regarding the IGH, the coefficients are slightly higher, but with opposite magnitude for direct effects, indicating that this character does not have the same relationship compared to DGH on grain yield. For IGH, the effects that show higher FPI presents no positive effects on grain yield.
For PH in Independência - RS, the DGH (Table 1) expressed intermediate and positive coefficient of correlation for direct effects, being the total correlation lower due to negative indirect effects of PNMS on PH. For Tenente Portela - RS, the same magnitudes are not observed, where estimates are lower for both total correlation and direct effects. According to Komari et al. (2004), plant height is a trait that suffers influence of population density, environment, cultural practices, sowing time, nutritional management, revealing that environment reduces the magnitude of correlations. The same pattern is observed for IGH cultivars in both environments. In Independência - RS, direct effects are positive and high, even higher than the total correlation, indicating a causal relationship. Similar results were obtained by Carvalho et al. (2002) who reported direct relationship of PH with GY. For the conditions of Tenente Portela - RS, the magnitudes are lower, in a similar behavior of DGH. Studies revealed that correlation coefficients of reduced or null magnitudes are due to environmental effects (Pinto et al., 1995; Strobel et al., 2016).

Regarding the component PNMS, direct effects (0.55) was observed for Independência - RS; however, the effects for Tenente Portela - RS are quite lower, revealing that the environment is influencing and changing the character's magnitudes. Therefore, a selection through breeding would not consider this trait in this environment. When a IGH cultivar is analyzed, the environments are opposite, since the magnitudes verified in Tenente Portela - RS are higher than those verified in Independência - RS for PNMS on GY, indicating that yield components relations are altered depending on the habit and environment of cultivation. The correlation demonstrates oscillations in intensity, linearity and nonlinearity (Charnet et al., 2008). GY depends on the combination of several intrinsics of plant such as number of pods, grains per pod, grain yield per plant (Fontoura et al., 2006). Some characters may present more or less relation with GY, according to the environment. Bahry et al. (2013) reported that pods located on the main stem significantly contribute to soybean grain yield.

Regarding the correlation of RN with GY for DGH, both direct and total effects of this trait on GY was observed for Independência - RS, corroborating with Carpenter and Board (1997), where positive correlation coefficients are expressed between the insertion of ramifications in soybeans and grain yield. This indicates that a higher RN does not contribute to achieve higher grain yield. Contrasting result is obtained for Tenente Portela - RS, where the effects are positive. Then regarding $\mathrm{RN}$, the decision about which cultivar to choose depends on the environment, considering that cultivars of higher RN might be beneficial to GY only in one environment, and the other environment may not show linearity. The IGH cultivars revealed positive magnitude in Independência - RS, as same as DGH cultivars. However, the direct effects for Tenente Portela - RS are low, not revealing causal effects of this trait on RN. Therefore, the choice of growing habit to achieve higher yields should occur due to the growing environment, once the results were contrary.

Contradictory results between growing environments are attributed to climatic and soil variations, solar radiation quality and quantity, temperature, relative humidity, altitude (Jiang and Egli, 1993) and plants structural arrangement (Board et al., 1990). The plants express 
Table 1.Estimates of direct and indirect phenotypic effects of first pod insertion (FPI), plant height (PH), pods number on the main stem (PNMS) of soybeans for growth habits and environments.

\begin{tabular}{|c|c|c|c|c|}
\hline \multirow{2}{*}{ Effects } & \multicolumn{2}{|c|}{ Determined habit } & \multicolumn{2}{|c|}{ Indeterminate habit } \\
\hline & Independência & Tenente Portela & Independência & Tenente Portela \\
\hline \multicolumn{5}{|l|}{ First Pod Insertion (FPI) } \\
\hline Direct effects on (GY) & 0.1280 & 0.1539 & -0.1568 & -0.2566 \\
\hline Indirect effects through (PH) & 0.2500 & -0.0305 & 0.1278 & 0.0616 \\
\hline Indirect effects through (PNMS) & -0.4370 & -0.0039 & 0.0187 & -0.0611 \\
\hline Indirect effects through (PNR) & -0.0050 & 0.0008 & 0.0760 & -0.1090 \\
\hline Indirect effects through (RN) & 0.0150 & -0.0048 & -0.1255 & 0.0113 \\
\hline Indirect effects through (NONEGP) & 0.0720 & -0.0668 & -0.0001 & 0.0028 \\
\hline Indirect effects through (NTWOGP) & -0.0460 & 0.1017 & 0.0041 & -0.0529 \\
\hline Indirect effects through (NTRHEEGP) & -0.0090 & 0.3446 & -0.1742 & -0.0842 \\
\hline Indirect effects through (TGW) & -0.0180 & 0.0597 & 0.0735 & -0.0686 \\
\hline Total & -0.0430 & 0.5689 & -0.1662 & -0.5893 \\
\hline \multicolumn{5}{|l|}{ Plant Height (PH) } \\
\hline Direct effects on (GY) & 0.3810 & -0.0736 & 0.4940 & 0.1230 \\
\hline Indirect effects through (FPI) & 0.0840 & 0.0637 & -0.0405 & -0.1286 \\
\hline Indirect effects through (PNMS) & -0.3030 & 0.0008 & -0.0290 & 0.1854 \\
\hline Indirect effects through (PNR) & -0.0009 & -0.0218 & -0.0413 & 0.0034 \\
\hline Indirect effects through (RN) & -0.0302 & -0.0530 & 0.0260 & 0.0038 \\
\hline Indirect effects through (NONEGP) & 0.1159 & -0.0252 & -0.0297 & -0.0575 \\
\hline Indirect effects through (NTWOGP) & -0.0376 & 0.0644 & -0.0064 & 0.0187 \\
\hline Indirect effects through (NTRHEEGP) & 0.0163 & 0.1596 & 0.0772 & 0.0518 \\
\hline Indirect effects through (TGW) & -0.0345 & 0.0033 & -0.1314 & -0.1624 \\
\hline Total & 0.2117 & 0.1113 & 0.3530 & 0.0520 \\
\hline \multicolumn{5}{|l|}{ Pods Number on the Main Stem (PNMS) } \\
\hline Direct effects on (GY) & 0.5538 & 0.0440 & -0.0647 & 0.3182 \\
\hline Indirect effects through (FPI) & -0.1017 & -0.0130 & 0.0454 & 0.0490 \\
\hline Indirect effects through (PNMS) & -0.2087 & -0.0014 & 0.2249 & 0.0716 \\
\hline Indirect effects through (PNR) & 0.0053 & 0.0209 & -0.0439 & 0.1031 \\
\hline Indirect effects through (RN) & -0.0140 & 0.0262 & 0.0296 & -0.0082 \\
\hline Indirect effects through (NONEGP) & -0.1143 & 0.0720 & -0.0604 & -0.1040 \\
\hline Indirect effects through (NTWOGP) & 0.0521 & -0.1073 & -0.0079 & 0.0796 \\
\hline Indirect effects through (NTRHEEGP) & 0.0092 & -0.0459 & 0.1853 & 0.1426 \\
\hline Indirect effects through (TGW) & 0.0116 & -0.0572 & -0.0698 & -0.1055 \\
\hline Total & 0.2218 & -0.0570 & 0.2341 & 0.5851 \\
\hline Determination coefficient & 0.2964 & 0.7883 & 0.5450 & 0.7670 \\
\hline K Value & 5.2560 & 9.2596 & 6.7810 & 0.1230 \\
\hline Residual variable effect & 0.8380 & 0.4600 & 0.6740 & 0.4820 \\
\hline Determining variable & 0.0027 & 0.0067 & 0.0154 & 0.0291 \\
\hline
\end{tabular}

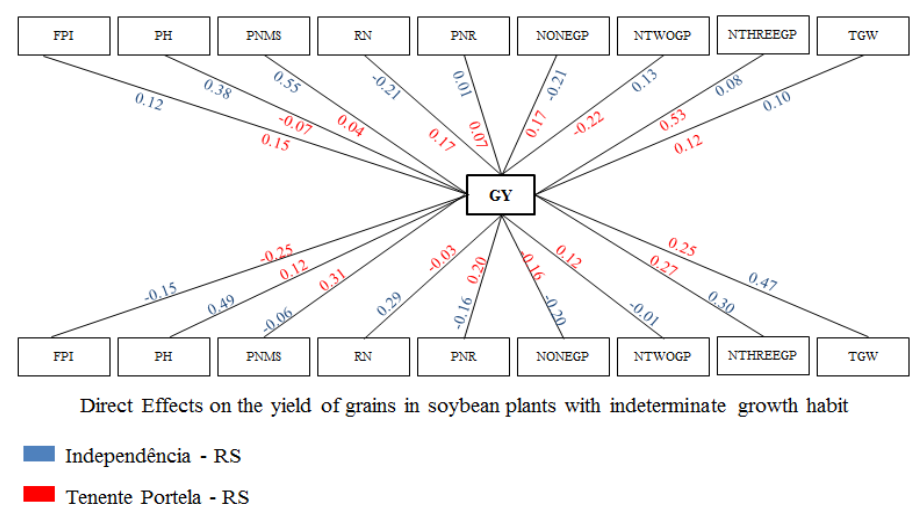

Fig 1. Path dendrogram for direct effect estimates of the traits first pod insertion height (FPI), plant height (PH), pods number on the main stem (PNMS), ramification number (RN), pods number on the ramification (PNR), number of one grain pods (NONEGP), number of two grains pods (NTWOGP), number of three grains pods (NTHREEGP), thousand grains weight (TGW) in relation to grain yield (GY), in soybean genotypes of determined and indeterminate growing habit cultivated in two growing environments (Independência and Tenente Portela - RS). 
Table 2. Estimates of direct and indirect phenotypic effects of ramifications number (RN), pods number on the ramifications (PNR) and number of one grain pods (NONEGP) of soybean genotypes for growth habits and environments.

\begin{tabular}{|c|c|c|c|c|}
\hline \multirow{2}{*}{ Effects } & \multicolumn{2}{|c|}{ Determined habit } & \multicolumn{2}{|c|}{ Indeterminate habit } \\
\hline & Independência & Tenente Portela & Independência & Tenente Portela \\
\hline \multicolumn{5}{|l|}{ Ramifications Number (RN) } \\
\hline Direct effects on (GY) & -0.2120 & 0.1795 & 0.2971 & -0.0333 \\
\hline Indirect effects through (FPI) & -0.0094 & -0.0041 & 0.0660 & 0.0870 \\
\hline Indirect effects through (PH) & 0.0541 & 0.0217 & 0.0438 & -0.0143 \\
\hline Indirect effects through (PNMS) & 0.0376 & 0.0064 & -0.0064 & 0.0787 \\
\hline Indirect effects through (PNR) & 0.0130 & 0.0674 & -0.1458 & 0.1478 \\
\hline Indirect effects through (NONEGP) & -0.0860 & 0.0203 & -0.0570 & -0.0520 \\
\hline Indirect effects through (NTWOGP) & -0.0860 & -0.0203 & -0.0082 & 0.0669 \\
\hline Indirect effects through (NTRHEEGP) & -0.0081 & 0.1974 & 0.1980 & 0.1464 \\
\hline Indirect effects through (TGW) & -0.0440 & 0.0364 & -0.0500 & 0.0385 \\
\hline Total & -0.1816 & 0.5150 & 0.3570 & 0.4610 \\
\hline \multicolumn{5}{|l|}{ Pods Number on the Ramifications (PNR) } \\
\hline Direct effects on (GY) & 0.0167 & 0.0722 & -0.1638 & 0.2014 \\
\hline Indirect effects through (FPI) & -0.0398 & 0.0018 & 0.0736 & 0.1401 \\
\hline Indirect effects through (PH) & -0.0221 & 0.0223 & 0.1249 & 0.0021 \\
\hline Indirect effects through (PNMS) & 0.1780 & 0.0120 & -0.0173 & 0.1630 \\
\hline Indirect effects through (RN) & -0.1750 & 0.1670 & 0.2645 & -0.0240 \\
\hline Indirect effects through (NONEGP) & -0.1015 & 0.0339 & -0.0578 & -0.0510 \\
\hline Indirect effects through (NTWOGP) & 0.0977 & -0.6390 & -0.0096 & 0.0831 \\
\hline Indirect effects through (NTRHEEGP) & -0.0003 & 0.1708 & 0.2201 & 0.2183 \\
\hline Indirect effects through (TGW) & -0.0264 & 0.0320 & -0.0844 & -0.0053 \\
\hline Total & -0.0720 & 0.4560 & 0.3389 & 0.7510 \\
\hline \multicolumn{5}{|l|}{ Number of One Grain Pods (NONEGP) } \\
\hline Direct effects on (GY) & -0.2155 & 0.1730 & -0.2021 & -0.1625 \\
\hline Indirect effects through (FPI) & -0.0430 & -0.0592 & -0.0001 & 0.0045 \\
\hline Indirect effects through (PH) & -0.2052 & 0.0107 & -0.0720 & 0.0435 \\
\hline Indirect effects through (PNMS) & 0.2939 & 0.0184 & -0.0193 & 0.2055 \\
\hline Indirect effects through (PNR) & 0.0078 & 0.0140 & -0.0469 & 0.0640 \\
\hline Indirect effects through (RN) & -0.0850 & 0.0210 & 0.0849 & -0.0106 \\
\hline Indirect effects through (NTWOGP) & 0.1013 & -0.1970 & -0.0021 & 0.0496 \\
\hline Indirect effects through (NTRHEEGP) & -0.0430 & -0.3440 & 0.0361 & 0.0466 \\
\hline Indirect effects through (TGW) & -0.0140 & -0.0700 & -0.0684 & -0.0880 \\
\hline Direct effects on (GY) & -0.2150 & -0.4170 & -0.1580 & 0.1326 \\
\hline Determination coefficient & 0.2964 & 0.7883 & 0.5450 & 0.7670 \\
\hline K Value & 5.2560 & 9.2596 & 6.7810 & 0.1230 \\
\hline Residual variable effect & 0.8380 & 0.4600 & 0.6740 & 0.4820 \\
\hline Determining variable & 0.0027 & 0.0067 & 0.0154 & 0.0291 \\
\hline
\end{tabular}

Table 3. Estimates of direct and indirect phenotypic effects of number of two grain pods (NTWOGP), number of three grain pods (NTHREEGP), and thousand grains weight (TGW) of soybean genotypes for growth habits and environments.

\begin{tabular}{lllll}
\hline \multirow{2}{*}{ Effects } & \multicolumn{2}{l}{ Determined habit } & & \multicolumn{2}{l}{ Indeterminate habit } \\
\cline { 2 - 3 } & Independência & Tenente Portela & & Independência \\
\hline Number of Two Grain Pods (NTWOGP) & & & -0.0142 & 0.1243 \\
\hline Direct effects on (GY) & 0.1350 & -0.2210 & 0.0453 & 0.1092 \\
Indirect effects through (FPI) & -0.0440 & -0.0700 & 0.2242 & 0.0185 \\
Indirect effects through (PH) & -0.1061 & 0.0214 & -0.0359 & 0.2038 \\
Indirect effects through (PNMS) & 0.2139 & 0.0213 & -0.1112 & 0.1347 \\
Indirect effects through (PNR) & 0.0120 & 0.0208 & 0.1710 & -0.0179 \\
Indirect effects through (RN) & -0.1356 & 0.0215 & -0.0308 & -0.0649 \\
Indirect effects through (NONEGP) & -0.1617 & 0.1540 & 0.1705 & 0.0995 \\
Indirect effects through (NTRHEEGP) & -0.0513 & -0.3430 & -0.1490 & -0.0588 \\
Indirect effects through (TGW) & -0.2927 & -0.0626 & 0.2689 & 0.5638 \\
Total & -0.1602 & -0.4790 & & 0.3085 \\
\hline Number of Three Grain Pods (NTHREEGP) & & & 0.0885 & 0.2741 \\
\hline Direct effects on (GY) & 0.0840 & 0.5310 & 0.1238 & 0.0788 \\
Indirect effects through (FPI) & -0.0140 & 0.0990 & -0.0389 & 0.0232 \\
Indirect effects through (PH) & 0.0734 & -0.0220 & 0.1655
\end{tabular}




\begin{tabular}{|c|c|c|c|c|}
\hline Indirect effects through (PNR) & 0.0000 & 0.0232 & -0.1169 & 0.1604 \\
\hline Indirect effects through (RN) & 0.0204 & 0.0660 & 0.1907 & -0.0178 \\
\hline Indirect effects through (NONEGP) & 0.1102 & -0.1125 & -0.0237 & -0.0276 \\
\hline Indirect effects through (NTWOGP) & -0.0815 & 0.1430 & -0.0078 & 0.0451 \\
\hline Indirect effects through (TGW) & 0.0176 & 0.0985 & -0.1192 & -0.0049 \\
\hline Total & 0.2755 & 0.8738 & 0.4259 & 0.7300 \\
\hline \multicolumn{5}{|l|}{ Thousand Grains Weight (TGW) } \\
\hline Direct effects on (GY) & 0.1068 & 0.1296 & 0.4773 & 0.2519 \\
\hline Indirect effects through (FPI) & -0.0218 & 0.0701 & -0.0240 & 0.0698 \\
\hline Indirect effects through (PH) & -0.1234 & -0.0019 & -0.1363 & -0.0793 \\
\hline Indirect effects through (PNMS) & 0.0601 & -0.0194 & 0.0094 & -0.1333 \\
\hline Indirect effects through (PNR) & -0.0041 & 0.0170 & 0.0289 & -0.0042 \\
\hline Indirect effects through (RN) & 0.0889 & 0.0500 & -0.0311 & -0.0051 \\
\hline Indirect effects through (NONEGP) & 0.0293 & -0.0947 & 0.0289 & 0.0568 \\
\hline Indirect effects through (NTWOGP) & -0.0370 & 0.1072 & 0.0044 & -0.0290 \\
\hline Indirect effects through (NTHREEGP) & 0.0140 & 0.4040 & -0.0770 & -0.0054 \\
\hline Total & 0.1185 & 0.6764 & 0.3129 & 0.1531 \\
\hline Determination coefficient & 0.2964 & 0.7883 & 0.5450 & 0.7670 \\
\hline K Value & 5.2560 & 9.2596 & 6.7810 & 0.1230 \\
\hline Residual variable effect & 0.8380 & 0.4600 & 0.6740 & 0.4820 \\
\hline Determining variable & 0.0027 & 0.0067 & 0.0154 & 0.0291 \\
\hline
\end{tabular}

plasticity caused by environmental fluctuations, in order to adapt themselves to environmental conditions (Rambo et al., 2004). Ballare et al. (1995) reported that ramification number and length is highly dependent on the solar radiation incident, and red and far red light spectrum, as soybeans tends to respond differently to environments for being characterized as a short-day plant. Indirect effect through (NTHREEGP) revealed low and positive correlation coefficient, and additions in this character could potentially affect GY. Navarro Junior et al. (2002) reported that ramifications contribute to soybean yield potential, increases the leaf area and lower rate of floral abscission. The total Pearson's correlation coefficient of $(0.515)$ is an intermediate and positive.

The PNR for DGH shows no significant direct effects in both environments, being influenced by cultural arrangement and genotype characteristics (Tourino et al., 2002). According to Amorim et al. (2008) the phenotypic correlation coefficients are grounded in genetic and environmental proportions. Navarro Junior et al. (2002) reported that an excessive number of ramifications demand quite large amount of assimilated products, which could be used in the formation of reproductive structures on the main stem. Regarding the IGH, direct effects are of low magnitude and inferior to the total effects. However, the environments present opposite magnitudes for PNR, for Cruz and Regazzi (1997) divergences between environments influence the relationship of the traits involved in the analysis.

The grain number in pod is a soybean yield component (Navarro Junior et al., 2002). Thus, this trait was divided in pods with one, two, and three grains, in order to verify which one presents more contribution to grain yield.

In Independência - RS, DGH revealed direct effects on NONEGP (Table 2) with low and negative correlation coefficients. The total Pearson correlation $(-0.215)$ showed low and negative coefficient, where the emission of pods with only one grain did not contribute to increase GY. In Tenente Portela - RS, direct effects of low magnitude and positive were evidenced on GY. Regarding the IGH, direct effects through NONEGP showed low and negative correlation coefficient in both locations. In Independência RS, the total Pearson's correlation coefficient ( $r$ : -0.158$)$ is low and negative. The total correlation coefficient is low and negative. Different results obtained for correlation coefficients are justified because the involved genes expression is influenced by environmental fluctuations, being responsible for the action of more than one trait (Santos and Vencovsky, 1986). Thus, for both growth habits, genotypes presenting the formation of pods with just one grain are not desirable because the effects on GY are not positive. Therefore, it is assumed that the formation of pods with more grains is favorable to increase GY.

In Independência - RS, the DGH effects for the trait NTWOGP (Table 3) revealed low and positive magnitudes related to the main character. The total Pearson's correlation $(r=-0.160)$ showed opposite magnitude, with inverse relationship of NTWOGP and the dependent variable. Studies conducted by Gomes et al. (2007) demonstrated the importance of analyzing correlation coefficients related to GY, and measuring the environment interference on the evaluated traits. In Tenente Portela - RS, the DGH was expressed through NTWOGP with low and negative direct effect on GY. The total Pearson's correlation $(-0.479)$ expressed negative intermediate coefficient for this environment. The differences between environments influenced the direct and indirect effects of grain yield parameters (Elias et al., 1999). The analysis of IGH at Independência - RS, revealed that direct effects through NTWOGP are null. The total Pearson's correlation (0.268) was low and positive. In Tenente Portela - RS, the trait revealed positive direct effects $(0.12)$ with moderate total magnitude of (0.56), which inflated by the indirect effects of PNMS on NTWOGP. Thomas and Costa (1994) reported that the number of grains per pod intrinsically attributes to the genotype. The formation of pods with viable ovules depends on the plant capacity for supplying the assimilated demand during the grain filling period (Maehler et al., 2003; Zimmer et al., 2016).

In Independência - RS, the NTHREEGP for DGH, absence of 
direct responses on GY was observed (Table 3). The total Pearson correlation (0.275) is low and positive. According to Vencovsky and Barriga (1992), null direct effects may be attributed to the indirect effects of variable response to the environment. In Tenente Portela - RS, the direct effects are characterized as intermediate and positive. The total Pearson's correlation was high and positive (0.873). The DGH was considerably influenced with the presence of pods with three grains to soybean yield. It demonstrated that along with the decomposition of pods number, pods with three grains revealed major contribution to increasing GY for DGH cultivars.

Regarding LGH, positive and considerably elevated direct effects were observed through NTHREEGP on GY in both environments, being the total magnitude even higher than direct estimates. Similar to DGH cultivars, IGH revealed superior magnitudes for GY with NTHREEGP, as genotypes with higher number of pods with three grains present potential to achieve larger yields. Positive correlations provide increment of independent variables and increase the dependent variable (Nogueira et al., 2012; Szareski et al., 2015).

The TGW showed positive direct effects on GY in both environments (Table 3) for DGH genotypes. According to Carvalho et al., (2002) soybean genotypes present plasticity to add or reduce the proportions of grains by facing different environmental conditions. Therefore, weight of thousand grains is a very important element for achieving high yields. Regarding the direct effects through TGW on GY for IGH, the correlation coefficients are positive in both environments, and the same magnitude is revealed to total effect. Thus, the thousand grain weight revealed positive association with grain yield, indicating that the selection of cultivars with increased thousand grain weight may result in greater final yield, regardless of the environment.

The results of this study justify the importance of this character for soybean performance, regardless of the environment and growing habit (determinate and indeterminate) through correlations of significant and positive magnitudes for all situations.

\section{Materials and methods}

\section{Experimental Conditions}

The experiments were conducted during one crop season. In Tenente Portela - RS state, the geographic coordinates are

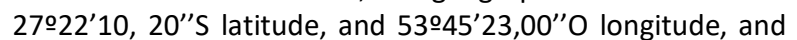
altitude of 420 meters. In Independência - RS state, the geographic coordinates are 07051'18, 14'S latitude, and 541'13,23" O longitude, and altitude of 315 meters. For both locations, the weather is classified as Cfa humid subtropical according to Köppen, and the soil is classified as typical distroferricoxisol.

\section{Experimental design and genotypes utilized}

The experimental design was randomized blocks arranged in factorial scheme, with (two growing environments) $x$ (four genotypes) in three replications. The genotypes with indeterminate growing habit (IGH) were: FPS Solimões RR and FPS Júpiter RR. The genotypes with determinate growth habit (DGH) were: BRS Tordilha RR and Fepagro 36 RR. Each experimental unity was composed by four lines of five meters length, spaced 0.45 meters. The population density for all genotypes was 300 thousand plants per hectare. For both locations of study, no-tillage system was used with fertilization based on the crop's demand, and the pests and diseases control occurred preventively.

The evaluations were conducted in the central lines of each experimental unit, discarding the first meters of the extremities to reduce the border effects. Posteriorly, ten plants were randomly sampled to obtain the parameters of agronomic interest, making the average of each variable for experimental unit.

\section{Evaluated traits}

- First pod insertion height (FPI): measured by the distance between the ground level and the insertion of the first pod on the main stem, in centimeters $(\mathrm{cm})$.

- Plant height (PH): measured by the distance from the ground level to the apex of the main stem, results in centimeters $(\mathrm{cm})$.

- Pods number on the main stem (PNMS): counting of the total number of viable pods attached to the main stem.

- Ramification number (RN): assessed by counting all plant ramifications.

- Pods number on the ramification (PNR): counting of the total number of pods inserted in all ramifications.

- Number of one grain pods (NONEGP): obtained by counting all pods with only one grain.

- Number of two grains pods (NTWOGP): obtained by counting all pods with only two grains.

- Number of three grains pods (NTHREEGP): obtained by counting all pods with three grains.

- Thousand grains weight (TGW): It was counted and determined the weight of eight subsamples with a hundred grains for each experimental unit, and then it was set for weight of a thousand grains, results expressed in grams.

- Grain yield (GY): obtained by the total weight of grains per experimental unit with correction of grain humidity to $13 \%$, and calculated the ratio of grains weight per plot by the number of plants. The grain weight per plant was adjusted to the density used, and the results were expressed in $\mathrm{kg} \mathrm{ha}$ 1 .

\section{Statistical analysis}

The data were submitted to the Shapiro-Wilk test for normality (1965) and variation of variances homogeneity by Hartley (Ramalho et al., 2012), for all evaluated characters.

The analysis of variance was done at $5 \%$ of probability to reveal significant genotype $x$ environment interaction for each growth habit. After that, a linear correlation was sliced for each growing environment and growth habit. In the same way, the multicollinearity diagnostic was performed for each situation to identify the number of conditions of the linear association matrix. Posteriorly, a path analysis was performed for each growing environment and growth habit using grain yield as the dependent character, and the other characters were considered explanatory. In the path analysis, the estimates of direct and indirect effects were performed considering the statistic model: $y=p_{1} x_{1}+p_{2} x_{2}$ $+\ldots+p_{n} x_{n}+p_{e} u$; where $y=$ dependent variable grain yields; 
$\mathrm{x}_{1}, \quad \mathrm{x}_{2}, \ldots, \mathrm{x}_{\mathrm{n}}:$ explanatory variables; $\mathrm{p}_{\mathrm{a}}, \mathrm{p}_{2}, \ldots \mathrm{p}_{\mathrm{n}}:$ path coefficients.

The path coefficients were estimated according to the system of equations $X^{\prime} X \beta=X^{\prime} Y(L I, 1975)$, where:

$$
X^{\prime} Y=\left(\begin{array}{c}
r_{1 y} \\
r_{2 y} \\
\vdots \\
r_{n y}
\end{array}\right), X^{\prime} Y=\left(\begin{array}{cccc}
1 & r_{12} & \ldots & r_{1 n} \\
r_{12} & 1 & \ldots & r_{2 n} \\
\vdots & \vdots & \ddots & \vdots \\
r_{1 n} & r_{2 n} & \ldots & 1
\end{array}\right) \text { e } \beta=\left(\begin{array}{c}
p_{1} \\
p_{2} \\
\vdots \\
p_{n}
\end{array}\right)
$$

Thereby, deploying the correlation between the dependent variable and the explanatory variable as shown below (Cruz et al., 2004):

$$
\begin{gathered}
r_{1 y}=p_{1}+p_{2} r_{12}+\ldots+p_{n} r_{1 n} \\
r_{2 y}=p_{1} r_{12}+p_{2}+\ldots+p_{n} r_{2 n} \\
\ldots . \ldots \\
r_{n y}=p_{1} r_{1 n}+p_{n 2}+\ldots+p_{n} \\
r_{i y}=p_{i}+\sum_{j \neq i}^{n} p_{j} r_{i j}
\end{gathered}
$$

Where:

$r_{i y}$ : correlation between the main variable selected by the researcher $(\mathrm{y})$ and the $\mathrm{i}^{\text {th }}$ explanatory variable:

$\mathrm{p}_{\mathrm{i}}$ : measure of the $\mathrm{i}$ variable direct effect on the main variable;

$p_{i} r_{i j}$ : measure of the $i$ variable indirect effect, through $j$ variable, on the main variable.

As stated by Cruz et al. (2004), when the variable elimination is not desirable for researcher, other procedures similar to ridge path analysis might be adopted. In this methodology, it is assumed that in presence of multicollinearity, the least square estimator obtained for $X^{\prime} Y$ may be linked to very high variances. This adverse effect can be slightly modified in the normal equation system introducing the constant $\mathrm{K}$ on the diagonal matrix $X^{\prime} X$. Thus, the path coefficients were obtained through: $\left(\mathrm{X}^{\prime} \mathrm{X}+\mathrm{KI}\right) \sigma=\mathrm{X}^{\prime} \mathrm{Y}$;

$\sigma=\left[\begin{array}{c}p_{1}^{*} \\ p_{2}^{*} \\ \cdots \\ p_{n}^{*}\end{array}\right]$

By including the constant $K$, the decomposition of correlation between explanatory variables and basic variable is given by:

$r_{1 y}=(1+K) p_{1}^{*}+p_{2}^{*} r_{12}+\ldots+p_{n}^{*} r_{1 n}$

$p_{1}^{*} r_{12}+(1+K) p_{2}^{*}+\ldots+p_{n}^{*} r_{2 n}$

$r_{n y}=p_{1}^{*} r_{1 n}+p_{2}^{*} r_{n 2}+\ldots+(1+K) p_{n}^{*}$

Then, we have:

$$
r_{i y}=(1+K) p_{1 i}^{*}+\sum_{j \neq i}^{n} p_{j}^{*} r_{i j}
$$

There were considered values from 0 to 1 for K. Cruz (1997) explained that lower constant value should be chosen, for which most of the path coefficients linked to several characters are stabilized. The path diagram determination is given by:

$R^{2}=p_{1} r_{1 y}+p_{2} r_{2 y}+\ldots+p_{n} r_{n y}$

The residual effect is estimated through:

$\rho_{\varepsilon=\sqrt{1-R^{2}}}$

Analyses were performed through the Genes statistic software (Cruz, 2013).

\section{Conclusion}

The components such as number of pods on the main stem, number of ramifications, number of pods in the ramifications, and number of one- and two-grain pods presented contrasting results for growing environments.

The number of three-grain pods is among the components that mostly related to grain yield in both determinate and indeterminate cultivars, regardless of environment. The adoption of cultivars with higher weight of a thousand grains may provide satisfactory results for grain yield, regardless of growth habit and environment of cultivation.

\section{Acknowledgement}

The authors wish to thank the National Council for Scientific and Technological Development (CNPq), and the Coordination for the Improvement of Higher Education Personnel (CAPES), for the support.

\section{References}

Almeida RD, Peluzio JM, Afferri FS (2010) Phenotypic, genotypic and environmental correlations in soybean cultivated under an irrigated meadow in south of Tocantins state. Biosc J. 26:95-99.

Amorim EP, Ramos NP, Ungaro MRG, Kiihl TAM (2008). Correlations and path analysis in sunflower. Bragantia. 67:307-316.

Ballaré CL, Scopel AL, Sánchez RA (1995) Plant photomorphogenesis in canopies, cropgrowh, and yield. Hort Sci. 30:1172-118.

Bahry CA, Venske E, Nardino M, Fin SS, Zimmer PD, Souza VQ, Caron BO (2013) Urea application in reproductive phase soybean and its effect on agronomic characters. Tecnol Ciênc Agrop. 7:9-36.

Baigorri H, Gassen D (2009) A importância do ciclo, da juvenilidade e do hábito de crescimento no manejo da cultura. Rev Plantio Direto. 109: 15-18.

Board JE. Harville BG, Saxton AM (1990) Branch dry weight in relation to yield increases in narrow-row soybean. Agron J. 82: 540-544

Borem A (2000) Escape gênico: os riscos do escape gênico da soja no Brasil. Biotecnologia Ciência e Desenvolvimento 10: 101-107.

Carpenter AC, Board JE (1997) Growth dynamic factors controlling soybean yield stability across plant populations, Crop Sci. 37:1520-1526.

Carvalho CGP, Arias CAA, Toledo JFF, Oliveira MF (2002) Correlation and path analyses in soybean lines sowed at different sowing dates. Braz J Agric Res. 37:311-320.

Charnet RRT (2008) Análise de modelos de regressão linear. Campinas. 357p.

Cruz CD (2013). GENES - a software package for analysis in experimental statistics and quantitative genetics. Acta Scient. 35(3): 271-276.

Cruz CD, Regazzi AJ (1997) Modelos biométricos aplicados ao melhoramento genético, ed. 2, Viçosa. 390p.

Cruz CD, Regazzi AJ, Carneiro PCS (2004) Modelos biométricos aplicados ao melhoramento genético, 3 ed. Viçosa, 480p.

Elias F, Clarke SM, Peck R, Terentjev EM (1999) Equilibrium textures in main-chain liquid crystalline polymers. 
Europhysics Letters. 47:442-448.

Fontoura TB, Costa JÁ, Daros E (2006) Effects on levels of defoliation and growth stage on yield and seed yield components of soybean. Scient Agr. 7:49-54.

Falconer DS (1987) Introdução à genética quantitativa. Viçosa, Imprensa Universitária, 279p.

Gomes CN, Carvalho SP, Jesus MAS, Custódio TN (2007) Morpho agronomic characterization and path analysis of production components in cassava clones. Braz J Agric. Res. 42:1121-1130.

Jiang H, Egli DB (1993) Shade induced changes in flower and pod number and flower and fruit abscission in soybean, Agron J. 85: 221-225.

Li CC (1975) Path analysis: a primer. Boxwood, Pacific Grove. 346p.

Maehler AR, Costa JA, Pires JLF, Rambo L 2003 Qualidade de grãos de duas cultivares de soja em função da disponibilidade de água no solo e arranjo das plantas. Ciênc Rural, 33: 213-218.

Mundstock, CM. Thomas AL (2005) Soja: fatores que afetam o crescimento e o rendimento de grãos. Porto Alegre: Departamento de Plantas de Lavoura da Universidade Federal do Rio Grande do Sul: 31p

Navarro JHM, Costa JÁ (2002) Relative contribution of yield components for grain production in soybean. Braz J Agric Res.37:269-274.

Nogueira APO, Sediyama T, Sousa LB, Hamawaki OT, Cruz CD, Pereira DG, Matsuo E (2012) Path analysis and correlations among traits in soybean grown in two dates sowing. Biosc J, 28:877-888.

Pandini F, Vello NA, Lopes ACA (2002) Heterosis in soybeans for seed yield components and associated traits. Brazilian Archives of Biology and Technology. 45: 401-412.

Pipolo VC, Gastaldi LF, Pipolo AE (2005) Correlações fenotípicas entre caracteres quantitativos em soja. Semina: Ciências Agrárias. 26: 11-16.

Pinto RJB (1995) Introdução ao melhoramento genético de plantas. Maringá. 56.

Ramalho MAP, Ferreira DF, Oliveira AC (2012) Experimentação em genética e melhoramento de plantas, 3: 305p.
Rambo L, Costa J, Pires JLF, Parcianello G, Ferreira, FG (2004) Yield potential estimated by soybean canopy stratum in response to plant arrangement. Ciênc Rural. 34:33-40.

Sediyama T (2009) Cultura da Soja - I Parte. 3 Reimpressão. Viçosa, $96 \mathrm{p}$.

Santos J, Vencovsky R (1986) Genetic control of some plant architecture components in dry bean, Ciência e Prática, 10: 265-272.

Shapiro SS, Wilk MB (1965) Analysis of Variance Test for Normality (Complete Samples). Biometrika. 52: 591-611.

Strobel T, Koch F, Aisenberg GR, Szareski VJ, Carvalho IR, Nardino M, Souza VQ, Villela FA, Pedo T, Aumonde TZ (2016) Physical and physiological quality of soybean seeds harvested under different trial systems after storage period. Aust J Basic Appl Sci. 10(13): 124-130.

Szareski VJ, Carvalho IR, Nardino M, Pelegrin AJ, Ferrari M, Gaviraghi R, Demari GH, Follmann DN, Warths CA, Souza (2016) Competition of soybean genotypes cultivated in lowlands of Rio Grande do Sul, Brazil, International Journal of Current Research. 8(10): 39714-39718.

Szareski VJ, Souza VQ, Carvalho IR, Nardino M, Follmann DN, Demari GH, Ferrari M, Olivoto T (2015) Growing environment and its effects on morphological characters and dietetic soy. Rev Bras de Agro Pecuária Sustentável (RBAS), 5(2): 79-88.

Tourino MCC, Rezende PM, Salvador N (2002) Row spacing, plant density and intrarow plant spacing uniformity effect on soybean yield and agronomic characteristics. Braz J Agric Res. 37: 1071-1077.

Thomas AL, Costa J (1994) Influence of water deficits on soybean development and yield.Braz. J Agric Res. 29-13891396.

Vencovsky R, Barriga P (1992) Genética biométrica no fitomelhoramento. Rer Bras Genét. 496p.

Wright S (1921) Correlation and causation. J Agric R. 20:557585.

Zimmer G, Koch F, Carvalho IR, Szareski VJ, Demari GH, Nardino M, Follmann DN, Souza VQ, Aumonde TZ, Pedo T (2016) Seed quality and initial performance os seedlings of soybean produced off-season in Rio Grande do Sul, Brasil. International Journal of Current Research. 8(10): 40325 40329. 